\title{
Shipping Information System in Distribution Warehouses Using a Web-Based Barcode System
}

\section{Sistem Informasi Pengiriman Barang di Gudang Distribusi Menggunakan Sistem Barcode Berbasis Web}

\author{
Dony Samara ${ }^{1}$, Mushlihudin ${ }^{2}$ \\ ${ }^{1}$ Mahasiswa Program Studi Teknik Elektro, Universitas Ahmad Dahlan, Indonesia \\ ${ }^{2}$ Dosen Program Studi Teknik Informatika, Universitas Ahmad Dahlan, Indonesia \\ Kampus 4 Jl. Ringroad Selatan, Kragilan, Tamanan, Kec. Banguntapan, Bantul, Daerah Istimewa Yogyakarta 55191
}

\section{INFORMASI ARTIKEL \\ Riwayat Artikel: \\ Dikirimkan 15 Agustus 2019, Direvisi 01 Desember 2019, Diterima 02 April 2020.}

\section{Kata Kunci: \\ Sistem informasi, \\ Barcode, \\ NodeMCU, \\ Arduino, \\ Gudang.}

\section{Penulis yang Berkaitan: \\ Dony Samara, \\ Program Studi Teknik Elektro, Universitas Ahmad Dahlan, Cokrodipan, RT 03, RW 02, Triharjo, Wates, Kulon Progo, D.I. Yogyakarta, Indonesia.}

surel: dony.samara2@gmail.com

\begin{abstract}
ABSTRAK
One of the data in the industrial process is information on shipping goods in a distribution warehouse. This study proposes a web-based freight information system in a distribution warehouse with a barcode system as the naming management of goods. The barcode reading system uses a barcode scanner as a barcode label reader, with an Arduino microcontroller device and NodeMCU as a controller and communication device with the web. The localhost web-based information system was built using the XAMPP application. Display information system using a simple display on the browser page. The results obtained in this study have successfully built a barcodebased goods delivery management system, information about the goods is coded into a barcode. The barcode reading system has successfully read and communicated with the web, with experiments conducted using 100 barcode labels, the success of reading and sending data has shown good results. Goods delivery information system in a web-based distribution warehouse has also been successfully built with an average data storage time of 5.5 seconds.
\end{abstract}

Salah satu data dalam proses industri yaitu informasi pengiriman barang di gudang distribusi. Penelitian ini mengusulkan sebuah sistem informasi pengiriman barang berbasis web di sebuah gudang distribusi dengan sistem barcode sebagai manajemen penamaan barang. Sistem pembacaan barcode menggunakan barcode scanner sebagai pembaca label barcode, dengan perangkat mikrokontroler Arduino dan NodeMCU sebagai perangkat kontroler dan komunikasi dengan web. Sistem informasi berbasis web localhost dibangun menggunakan aplikasi XAMPP. Tampilan sistem informasi menggunakan tampilan sederhana di halaman browser. Hasil yang didapatkan dalam penelitian ini adalah telah berhasil dibangun sistem manajemen pengiriman barang berbasis barcode, informasi mengenai barang dikodekan kedalam bentuk barcode. Sistem pembacaan barcode telah berhasil membaca dan berkomunikasi dengan web, dengan percobaan yang dilakukan menggunakan 100 label barcode keberhasilan pembacaan dan pengiriman data telah menunjukkan hasil yang baik. Sistem informasi pengiriman barang di gudang distribusi berbasis web telah berhasil pula dibangun dengan lama penyimpanan data rata - rata 5,5 detik.

This work is licensed under a Creative Commons Attribution-Share Alike 4.0

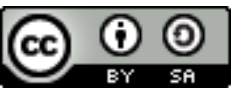

\section{Sitasi Dokumen ini:}

D. Samara and Muslihudin, "Shipping Information System in Distribution Warehouses Using a Web-Based Barcode System," Buletin Ilmiah Sarjana Teknik Elektro, vol. 2, no. 1, pp. 1-13, 2020. DOI: $\underline{10.12928 / \text { biste.v2i1.954 }}$ 


\section{PENDAHULUAN}

Industri di Indonesia sudah memasuki era industri 4.0, industri 4.0 merupakan revolusi industri secara global yang saat ini telah memasuki revolusi ke 4. Salah satu aspek dalam industri 4.0 yaitu jaringan komunikasi, terkait dengan penggunaan teknologi baik itu perangkat keras maupun lunak dalam rangka mendukung komunikasi secara cepat [1]. Penerapan aspek tersebut adalah dengan menerapkan sistem kerja yang diterapkan dalam industri 4.0 menggunakan IoT (internet of thing) [2], dimana terdapat beberapa data didalam proses industri yang perlu disalin kedalam basis data berbasis online yang dilakukan melalui komunikasi internet. Pada sisi produktivitas industri di Indonesia pada era 4.0 ini diprediksi akan lebih dapat meningkat, baik disisi kuantitatif maupun kualitatif.

Rantai kerja didalam kegiatan industri selain proses produksi, salah satu proses yang paling krusial adalah pada sistem logistik dan rantai pasok [3]. Setelah barang selesai diproduksi tentunya barang akan langsung dipindahkan dari area produksi. Pada proses pemindahan barang ini terjadi proses distribusi tahap pertama yang termasuk kedalam sistem logistik dan rantai pasok pada dunia industri. Peningkatan produktivitas yang telah diprediksi, maka dibutuhkan sistem logistik dan rantai pasok yang handal.

Salah satu sistem logistik dan rantai pasok industri di Indonesia terdapat satu bagian yang sangat penting yaitu gudang distribusi [4]. Gudang distribusi berfungsi menyimpan barang - barang hasil produksi untuk sementara waktu, sebelum barang tersebut didistribusikan ke pelanggan ketika dibutuhkan. Dengan adanya gudang pusat distribusi biaya pengiriman akan lebih murah dibanding dengan proses pengiriman produk yang langsung dari pabrik ke beberapa lokasi pelanggan.

Revolusi industri telah memasuki era industri 4.0 menjadikan kebutuhan akan manajemen yang handal didalam gudang distribusi menjadi hal yang cukup mendesak. Penerimaan dan pengiriman barang perlu dicatat dengan baik sehingga akan tercapai manajemen gudang yang baik. Dewasa ini penerapan teknologi telah diadopsi oleh industri maupun perusahaan di Indonesia. Tidak terkecuali pada manajemen penerimaan dan pengiriman barang pada gudang distribusi.

Manajemen berbasis teknologi pada gudang distribusi memiliki hardware dan software yang dikombinasikan menjadi sebuah sistem yang dapat mengolah data inventaris sekaligus sebagai sistem informasi inventaris di gudang distribusi. Salah satu komponen penting dalam sistem ini adalah basis data (database) dan antarmuka pengguna grafis atau lebih familiar dengan istilah graphical user interface (GUI). Basis data berperan dalam pengolahan data dan GUI memiliki peran sebagai antarmuka atau sistem informasi inventaris barang. Penelitian yang dilakukan oleh Risna 'Ainun C.N. dan Arfan Bakhtiar menggunakan aplikasi barcode telah menghasilkan sistem informasi inventaris material di gudang kimia dan waktu kapan material harus di pesan lagi [5]. Pengaplikasian barcode dalam penelitian tersebut sudah cukup baik, penelitian ini menggunakan pengembangan dari apliaksi barcode dengan tujuan yaitu menentukan tujuan kirim dan identitas dari barang di suatu gudang distribusi. Pemanfaatan barcode dalam membentuk aplikasi sistem berbasis teknologi sangat baik dalam waktu dewasa ini, karena kemampuannya mengubah berbagai informasi menjadi kode visual yang sangat ringkas.

Sistem informasi yang baik menjadi tujuan utama dari pembangunan sistem informasi didalam industri. Penelitian yang dilakukan Hana Khikmatul Muna Shofa membuat prototype sistem informasi persediaan barang pada sebuah toko [6]. Menggunakan aplikasi visual basic sebagai tampilan dengan tujuan menggantikan sistem lama yang masih menggunakan microsoft excel, didapatkan hasil sistem informasi yang lebih ringkas dengan tampilan yang lebih menarik. Penelitian lain oleh Syahriani, Tri Santoso, dan Ahmad Putra Rizki menghasilkan sistem informasi berupa web pada manajemen penjualan disebuah toko furniture [7]. Menggunakan aplikasi XAMPP penelitian tersebut membangun sebuah sistem informasi berbasis web. Sistem informasi dalam penelitian ini menerapkan ide - ide dan pengembangan dari kedua penelitian tersebut, yaitu membentuk sistem informasi berbasis web yang user friendly.

Sistem informasi inventaris gudang distribusi saat ini masih berupa sistem yang berorientasi offline. Demi mendukung revolusi industri 4.0 sistem informasi inventaris gudang distribusi perlu ditingkatkan menjadi sistem yang berorientasi online. Dalam penelitian ini dibuat suatu sistem informasi pengiriman barang di sebuah gudang distribusi berbasis web. Dimana dengan menggunakan basis web maka sistem ini telah menjadi sistem yang berorientasi online.

\section{METODE PENELITIAN}

Penelitian yang dilakukan adalah dengan membuat sebuah sistem informasi berbasis web yang berisi informasi mengenai transaksi pengiriman barang di sebuah gudang distribusi. Setiap barang memiliki infomasi mengenai nama dan tujuan barang akan dikirim. Informasi tersebut berbentuk label barcode yang ditempelkan pada barang. Sistem informasi kemudian ditampilkan dihalaman browser. 


\subsection{Desain Sistem}

Sistem dalam penelitian ini membutuhkan kombinasi antara hardware dan software. Komponen hardware untuk mengakomodasi sistem barcode dan software sebagai database dan GUI (graphical user interface) dari sistem. Blok diagram desain sistem ditunjukkan oleh Gambar 1.

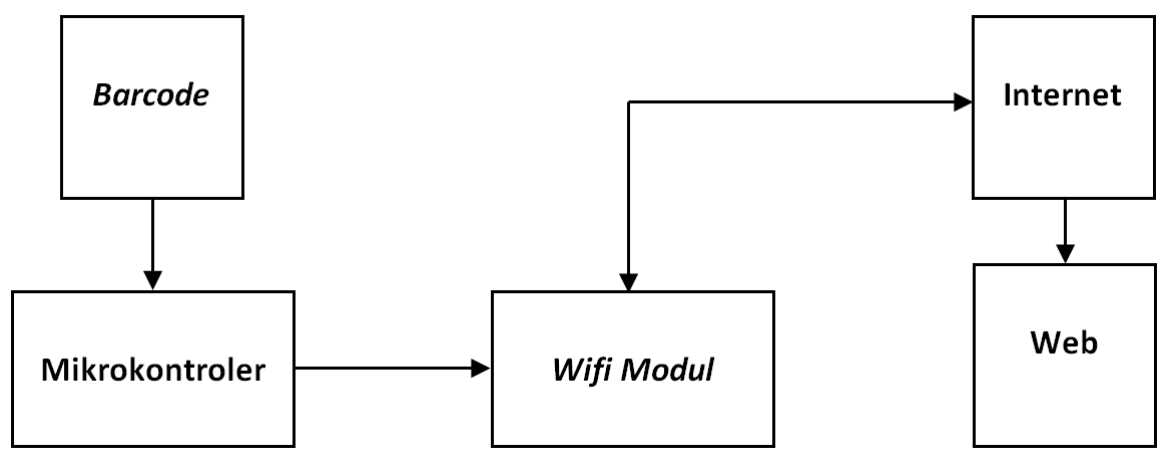

Gambar 1. Diagram blok desain sistem

Peran dari masing-masing komponen pada blok diagram diatas adalah diantaranya sebagai berikut, barcode sebagai identitas barang yang akan dikirim. Mikrokontroler sebagai otak dari sistem, yaitu mengolah informasi barcode yang terbaca dan mengirimkannya ke modul wifi. Modul wifi berperan mengirim informasi yang diterima dari mikrokontroler ke web melalui komunikasi internet. Kemudian web berperan sebagai database sekaligus sebagai GUI (Graphical User Interface) dari sistem ini.

\subsubsection{Hardware}

Hardware dalam sistem ini memiliki 2 peran utama, sebagai pembaca barcode, komunikasi dengan server dan sebagai server itu sendiri. Blok diagram hardware ditunjukkan oleh Gambar 2.

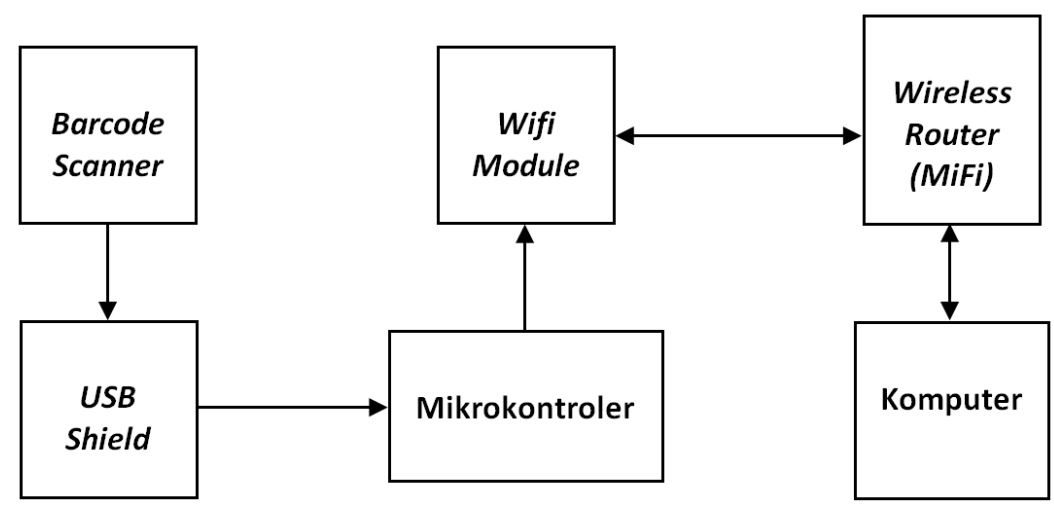

Gambar 2. Diagram blok perancangan hardware

Hardware pertama yang digunakan adalah barcode scanner sebagai pembaca kode barcode yang berisi identitas barang. Selanjutnya digunakan modul USB sebagai perantara komunikasi antara barcode scanner dengan mikrokontroler. Hardware yang ketiga yaitu mikrokontroler sebagai otak dalam sistem pembacaan barcode, menerima dan mengolah data hasil scan barcode scanner. Setelah itu wifi module berperan mengirim data ke web melalui komunikasi internet. Wifi module yang digunakan dalam penelitian ini adalah sebuah mikrokontroler dengan kemampuan komunikasi internet. Setelah menerima data dari mikrokontroler, menggunakan komunikasi wireless yaitu komunikasi internet perangkat ini mengirim data ke komputer. Hardware yang ke 3 yaitu wireless router, perangkat ini berperan sebagai pemberi koneksi internet bagi wifi module dan komputer. Komunikasi yang terjadi antara wifi module dan komputer adalah komunikasi internet dengan router sebagai perangkat penengah. Selanjutnya hardware yang terakhir yaitu komputer, tempat dibangunnya web berbasis localhost dimana semua sistem web berjalan. Komputer sebagai server, penyimpan data, manipulator, dan sebagai penampil sistem informasi. Gambar 3 merupakan konfigurasi hardware pembaca dan Gambar 4 merupakan keseluruhan hardware yang dibangun dalam penelitian. 


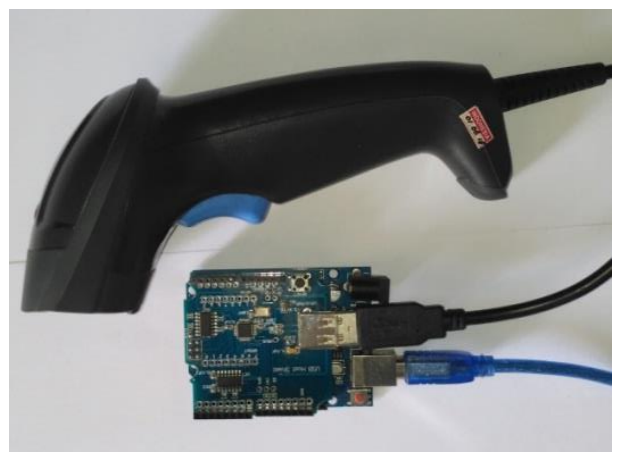

Gambar 3. Konfigurasi hardware pembaca barcode

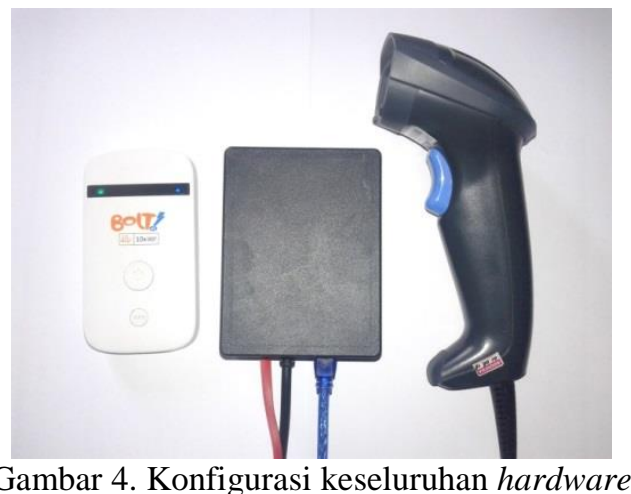

Informasi yang memuat tentang keterangan dari barang yang akan dikirim dimuat dalam sebuah label barcode. Dalam penelitian dibuat purwarupa kerja sebuah gudang distribusi regional yang melayani pengiriman 3 kota besar di Indonesia yaitu Yogyakarta, Semarang, dan Surabaya. Kemudian dirancang label barcode dibatasi hanya sejumlah 100 buah. Selanjutnya dalam penelitian ini didapatkan alokasi untuk masing - masing kota tujuan sebanyak masing - masing 33, 33, dan 34.

Langkah selanjutnya yaitu memasukkan perancangan basis data kedalam sebuah kode berjenis barcode. Jumlah kombinasi kode pada barcode dibatasi sebanyak 13 karakter berbentuk angka. Selanjutnya kode dialokasikan untuk pengkodean barang, 3 digit pertama sebagai kode kota tujuan dan 10 digit terakhir sebagai kode nama dari barang. Implementasi rancangan barcode ditampilkan dalam Gambar 5.

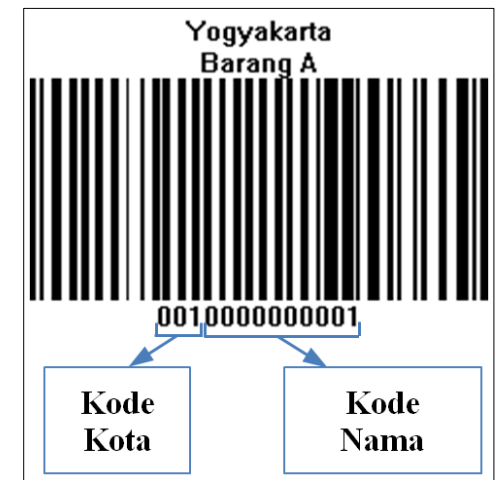

Gambar 5. Rancangan label barcode

\subsubsection{Software}

Sistem yang dibangun dalam penelitian ini adalah sistem berbasis web localhost menggunakan aplikasi XAMPP. Didalam sebuah sistem web terdapat beberapa komponen utama, diantaranya adalah basis data dan GUI (graphical user interface). Gambar 6 menunjukkan basis data yang dibangun dalam penelitian ini. 


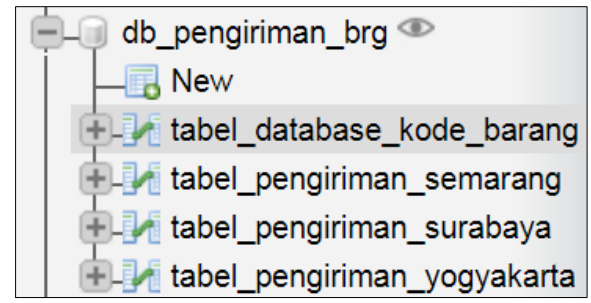

Gambar 6. Basis data web

Terdapat 4 buah basis data yang berada dibawah atau merupakan sub - sub dari basis data utama. Basis data yang pertama berkaitan dengan kode barang (produk) yaitu semua produk yang disimpan di gudang distribusi. Basis data yang kedua yaitu berkaitan dengan barang yang dikirim ke kota Semarang. Basis data yang ketiga yaitu berkaitan dengan barang yang dikirim ke kota Surabaya. Selanjutnya Basis data yang terakhir yaitu berkaitan dengan barang yang dikirim ke kota Yogyakarta.

Bagian akhir dari sistem ini adalah sebuah tampilan web. Tujuan dari dibuatnya tampilan web adalah web sebagai sistem informasi yang dapat memberikan informasi se-informatif mungkin kepada pengguna. Dalam penelitian ini dibangun tampilan web pada halaman browser menggunakan pemrograman html. Gambar 7 merupakan rancangan web GUI sistem informasi dalam penelitian ini.

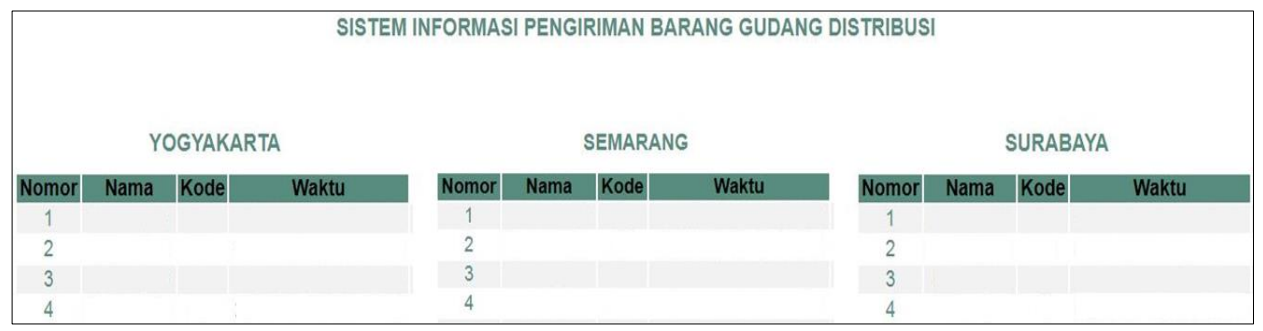

Gambar 7. Tampilan sistem informasi

\subsubsection{Algoritma}

Setelah rancangan software dan hardware berhasil diwujudkan dalam konfigurasi sistem yang utuh, perlu dibuat algoritma kerja dari sistem tersebut. Algoritma yang diwujudkan kedalam perintah kerja berupa program yang harus dijalankan oleh sistem. Terdapat beberapa bahasa pemrograman yang digunakan dalam sistem ini, diantaranya adalah C(arduino), php dan html. Hardware menggunakan bahasa C(arduino), sedangkan software menggunakan bahasa pemrograman web yaitu php dan html. Gambar 8 merupakan algoritma kerja berupa flowchart dari hardware mikrokontroler pertama yaitu arduino uno.

Secara sederhana cara kerja flowchart pada Gambar 8 adalah yang pertama, dilakukan inisialisasi pustaka - pustaka (libraries), variabel - variabel, dan sub - sub program yang digunakan. Langkah yang kedua yaitu menghubungkan mikrokontroler dengan USB shield, yang merupakan perantara komunikasi USB antara mikrokontroler dengan barcode scanner. Selanjunya bila sudah terhubung dengan perangkat USB shield, mikrokontroler melakukan pembacaan terhadap data masukan dari USB shield. Pembacaan data tersebut dilakukan ketika terdeteksi barcode scanner telah selesai melakukan scan terhadap sebuah label barcode. Langkah terakhir adalah data yang terbaca kemudian diolah dan dikirim ke NodeMCU (wifi module). Apabila terjadi kondisi USB shield tidak terdeteksi maka akan dijalankan program untuk menghentikan pengolahan data dan akan dimunculkan peringatan bahwa perangkat tersebut tidak terdeteksi. Selanjutnya algoritma pemrograman untuk mikrokontroler yang kedua ditunjukkan oleh Gambar 9.

Secara sederhana cara kerja flowchart pada Gambar 9 adalah langkah pertama yang dilakukan yaitu inisialisasi pustaka - pustaka (libraries), variabel - variabel, dan sub - sub program yang digunakan. Kemudian langkah kedua yaitu menghubungkan dirinya dengan internet, dalam hal ini menghubungkan dirinya dengan perangkat MiFi. Selanjunya bila sudah terhubung dengan perangkat internet (MiFi), dilakukan pembacaan data yang masuk melalui komunikasi serial. Apabila terdapat data selanjutnya data langsung dikirim ke web berbasis localhost melalui komunikasi wireless yaitu internet.

Dalam sistem kerja program ini dimasukkan pula kondisi apabila perangkat tidak berhasil terkoneksi dengan internet, maka akan dilakukkan koneksi ulang dengan jangka waktu tertentu. Selanjutnya apabila tidak berhasil mengirim data ke web maka akan dimunculkan pesan peringatan. Algoritma terakhir yang dibangun dalam sistem ini adalah algoritma pada sistem web-nya. Selain berupa tampilan sistem informasi, web tentunya memiliki sistem kerja lain supaya web dapat berfungsi secara utuh. Gambar 10 menunjukkan algoritma yang dibangun dalam sistem kerja web. 


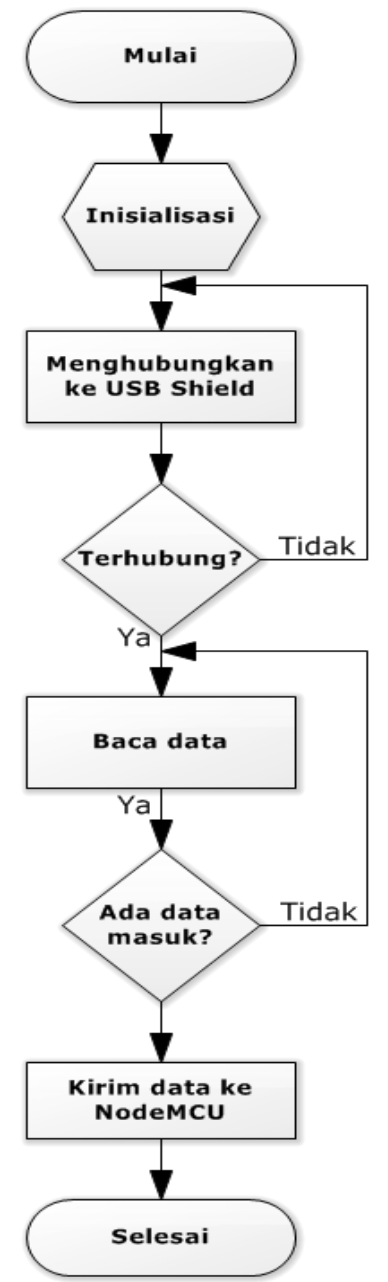

Gambar 8. Flowchart arduino uno

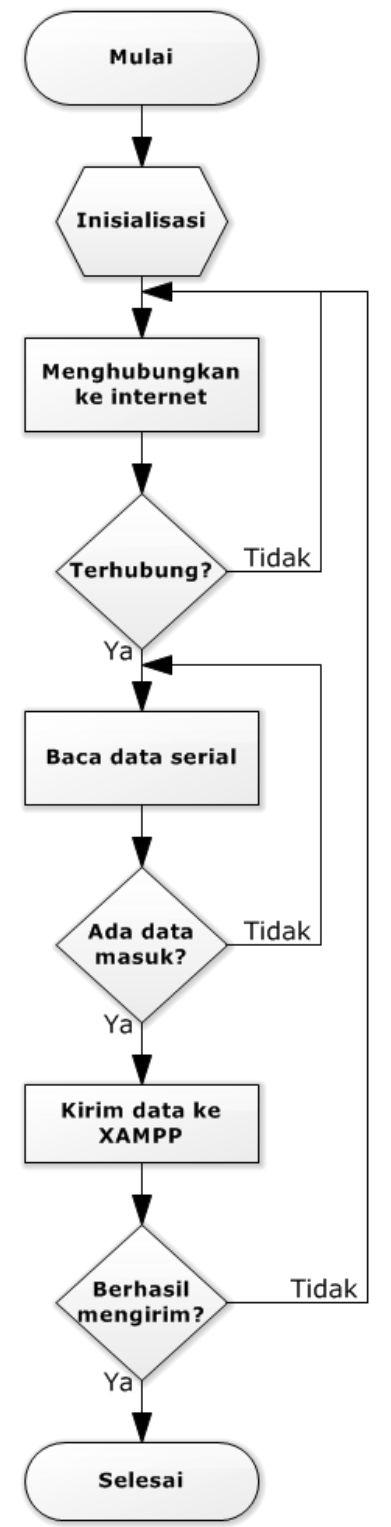

Gambar 9. Flowchart NodeMCU

Secara sederhana cara kerja dari flowchart pada Gambar 10 adalah langkah pertama yang dilakukan yaitu inisialisasi pustaka - pustaka (libraries), variabel - variabel, dan sub - sub program yang digunakan. Selanjutnya langkah kedua yaitu menghubungkan dengan web, dengan cara melakukan autentikasi pengguna sebagai admin untuk dapat mengakses basis data web yang telah dibangun. Langkah yang ketiga yaitu, bila sudah terhubung dengan basis data, dilakukan pengiriman atau penyimpanan data yang diterima dari NodeMCU kedalam basis data.

Dalam proses penyimpanan data terlebih dahulu dilakukan penyeleksian data berdasarkan kode kota tujuan pengiriman. Terdapat 3 tujuan pengiriman dengan 3 kode yang berbeda, data yang sesuai dengan kode akan disimpan ke masing - masing basis data berdasarkan kesesuaian kodenya. Setelah data berhasil disimpan, selanjutnya ditampilkan sistem informasi pengiriman barang di gudang distribusi dengan memanggil basis data tersebut untuk ditampilkan pada halaman browser yang merupakan komponen akhir dari keseluruhan sistem. 


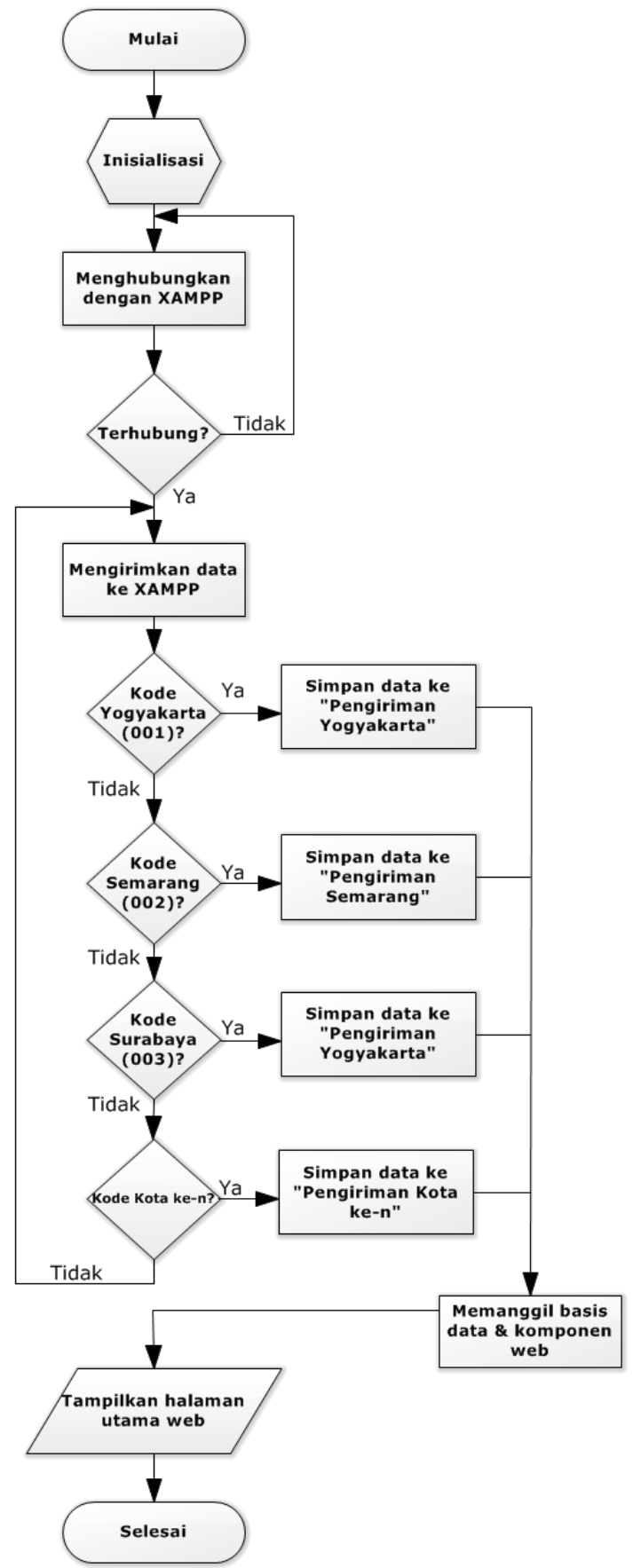

Gambar 10. Flowchart web

\section{HASIL DAN PEMBAHASAN}

Hasil akhir dari penelitian ini adalah sebuah sistem informasi pengiriman barang digudang distribusi, dengan sistem barcode digunakan dalam penamaan barang. Pada sub bab 3.1. ditampilkan hasil akhir dari penelitian ini, berupa tampilan sistem informasi. Pada sub bab 3.2. dan sub bab berikutnya dibahas mengenai kinerja sistem hasil penelitian. Kinerja sistem dinilai dengan melakukan beberapa pengujian terhadap sistem.

\subsection{Tampilan Sistem Informasi}

Sistem informasi diakses melalui browser yang ada di komputer server. Gambar 11 merupakan tampilan halaman utama sistem informasi. Berdasarkan Hasil tersebut dapat diketahi bahwa sistem informasi dapat bekerja dengan baik karena dapat menampilkan hasil pembacaan barcode dan database barang. 


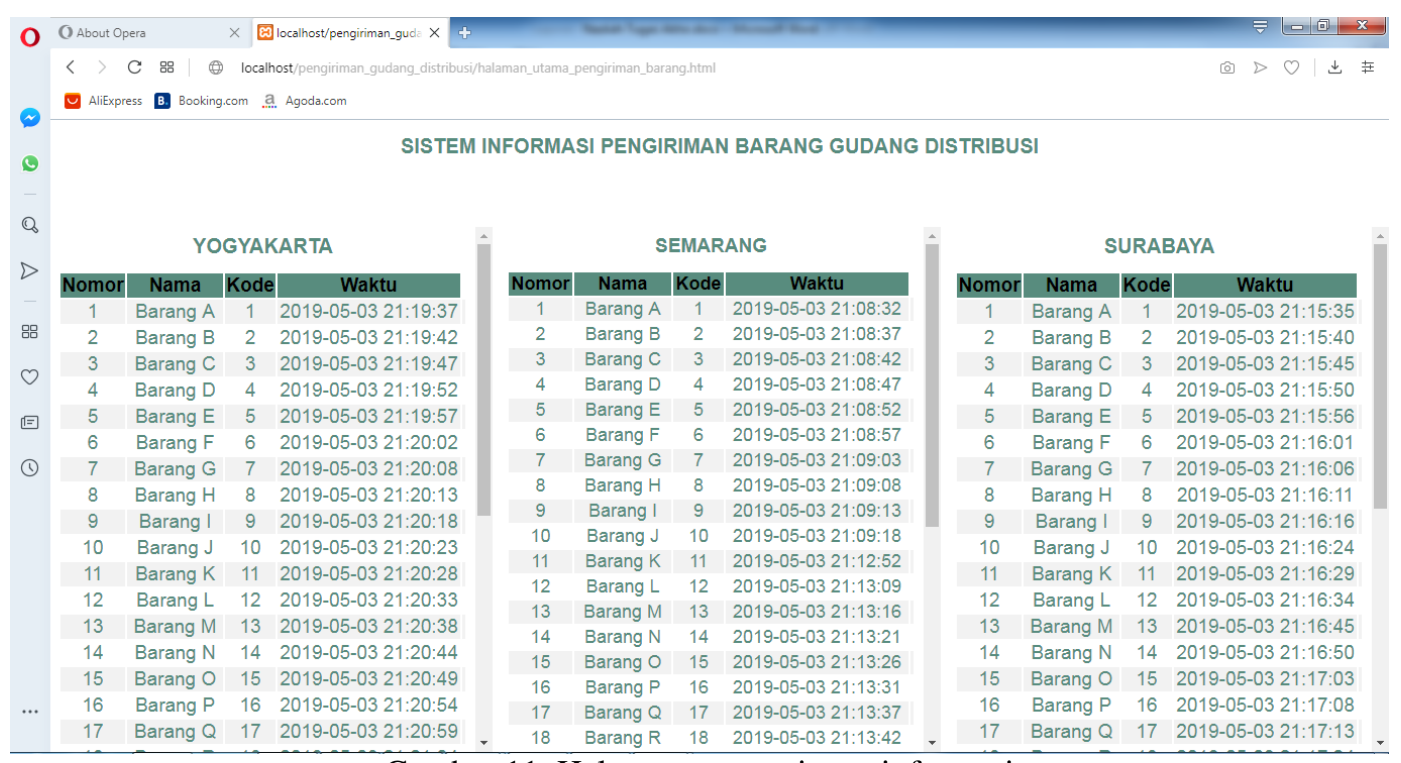

Gambar 11. Halaman utama sistem informasi

\subsection{Ketepatan Pembacaan Barcode}

Kerja dari sistem informasi pengiriman barang di gudang distribusi menggunakan sistem barcode tak lepas dari sistem pembacaan barcode. Sistem ini merupakan ujung tombak dari keseluruhan sistem. Menggunakan bahan penelitian yang telah dibuat yaitu berupa label barcode barang, dilakukan pengujian terhadap sistem. Tabel 1 merupakan hasil pengujian pembacaan barcode.

Tabel 1. Perbandingan Kode Aktual dengan Kode Terbaca Alat

\begin{tabular}{cccc}
\hline No. & Kode pada Label Barcode & Hasil Pembacaan Alat & Keterangan \\
\hline 1 & 0010000000001 & 0010000000001 & Sesuai \\
2 & 0010000000002 & 00100000000002 & Sesuai \\
3 & 0010000000003 & 0010000000003 & Sesuai \\
4 & 0010000000004 & 0010000000004 & Sesuai \\
5 & 0010000000005 & 00100000000005 & Sesuai \\
6 & 0010000000006 & 0010000000006 & Sesuai \\
7 & 0010000000007 & 0010000000007 & Sesuai \\
8 & 0010000000008 & 0010000000008 & Sesuai \\
9 & 0010000000009 & 0010000000009 & Sesuai \\
10 & 0010000000010 & 0010000000010 & Sesuai \\
\hline
\end{tabular}

Berdasarkan hasil pada Tabel 1 antara nilai kode pada label (aktual) dengan nilai yang terbaca oleh alat tidak terdapat perbedaan. Pengujian dengan pengambilan data yang dilakukan secara terus - menerus dalam satu sesi, dari 10 label barcode angka hasil pembacaan alat semuanya sesuai dengan angka aktual pada label barcode.

\subsection{Ketepatan Penyimpanan Data}

Penyimpanan data yang akan diuji dalam sub bab ini merupakan penyimpanan data yang bekerja secara otomatis, sedangkan di dalam sistem ada pula penyimpanan data yang dilakukan secara manual. Sistem penyimpanan data yang dilakukan pada tahap ini yaitu penyimpanan data pada basis data berdasarkan kota tujuan secara otomatis dengan mendeteksi 3 digit awal dari kode barang. Setiap kota tujuan memilki sub basis data tersendiri, data pengiriman barang disimpan pada masing - masing sub basis data sesuai kota tujuan pengiriman. Tabel 2 merupakan hasil pengujian ketepatan penyimpanan data pada kota tujuan pengiriman Yogyakarta.

Tabel 2. Ketepatan Penyimpanan Data pada Basis Data

\begin{tabular}{cccc}
\hline Kode Kota & Kode pada Label Barcode & Disimpan pada Basis Data & Keterangan \\
\hline Yogyakarta & 0010000000001 & Tabel_pengiriman_yogyakarta & Tepat \\
& 0010000000002 & Tabel_pengiriman_yogyakarta & Tepat \\
& 0010000000003 & Tabel_pengiriman_yogyakarta & Tepat \\
& 0010000000004 & Tabel_pengiriman_yogyakarta & Tepat
\end{tabular}




\begin{tabular}{cccc}
\hline Kode Kota & Kode pada Label Barcode & Disimpan pada Basis Data & Keterangan \\
\hline 0010000000005 & Tabel_pengiriman_yogyakarta & Tepat \\
0010000000006 & Tabel_pengiriman_yogyakarta & Tepat \\
0010000000007 & Tabel_pengiriman_yogyakarta & Tepat \\
0010000000008 & Tabel_pengiriman_yogyakarta & Tepat \\
0010000000009 & Tabel_pengiriman_yogyakarta & Tepat \\
0010000000010 & Tabel_pengiriman_yogyakarta & Tepat \\
\hline
\end{tabular}

Pada Tabel 2 sistem diberikan masukan data pengujian dengan data label barcode barang untuk tujuan pengiriman Yogyakarta sebanyak 10 buah label. Scan label barcode dilakukan secara terus - menerus dalam 1 sesi. Hasil yang didapat adalah dari 10 masukan data yang diberikan, penyimpanan data yang dilakukan oleh sistem secara tepat semuanya disimpan pada sub basis data "Tabel_pengiriman_yogyakarta". Sub basis data tersebut merupakan penyimpanan data barang tujuan pengiriman Yogyakarta.

\subsection{Jarak Maksimal dan Minimal Label Barcode Terbaca}

Pengujian dalam sub ini menguji kemampuan sistem terkait jarak maksimal dan minimal alat dapat membaca label barcode. Dilakukan pengujian dengan jarak paling minimal dan maksimal alat dapat membaca label barcode. Dilakukan pengujian pembacaan label barcode dengan jarak yang bervariasi, dimulai dari jarak terdekat sampai yang terjauh dimana scanner dapat membaca label barcode. Tabel 3 menampilkan hasil pengujian yang dilakukan.

Tabel 3. Jarak Maksimal dan Minimal Label Barcode Terbaca

\begin{tabular}{|c|c|c|c|}
\hline No. & Jarak (cm) & Sampel Barcode & Keterangan \\
\hline \multirow{3}{*}{1} & \multirow{3}{*}{0} & 1 & Tidak Terbaca \\
\hline & & 2 & Tidak Terbaca \\
\hline & & 3 & Tidak Terbaca \\
\hline \multirow{3}{*}{2} & \multirow{3}{*}{1} & 1 & Terbaca \\
\hline & & 2 & Terbaca \\
\hline & & 3 & Terbaca \\
\hline \multirow{3}{*}{3} & \multirow{3}{*}{2} & 1 & Terbaca \\
\hline & & 2 & Terbaca \\
\hline & & 3 & Terbaca \\
\hline \multirow{3}{*}{4} & \multirow{3}{*}{3} & 1 & Terbaca \\
\hline & & 2 & Terbaca \\
\hline & & 3 & Terbaca \\
\hline \multirow{3}{*}{5} & \multirow{3}{*}{4} & 1 & Terbaca \\
\hline & & 2 & Terbaca \\
\hline & & 3 & Terbaca \\
\hline \multirow{3}{*}{6} & \multirow{3}{*}{5} & 1 & Terbaca \\
\hline & & 2 & Terbaca \\
\hline & & 3 & Terbaca \\
\hline \multirow{3}{*}{7} & \multirow{3}{*}{6} & 1 & Terbaca \\
\hline & & 2 & Terbaca \\
\hline & & 3 & Terbaca \\
\hline \multirow{3}{*}{8} & \multirow{3}{*}{7} & 1 & Terbaca \\
\hline & & 2 & Terbaca \\
\hline & & 3 & Terbaca \\
\hline \multirow{3}{*}{9} & \multirow{3}{*}{8} & 1 & Terbaca \\
\hline & & 2 & Terbaca \\
\hline & & 3 & Terbaca \\
\hline \multirow{3}{*}{10} & \multirow{3}{*}{9} & 1 & Terbaca \\
\hline & & 2 & Terbaca \\
\hline & & 3 & Terbaca \\
\hline \multirow{3}{*}{11} & \multirow{3}{*}{10} & 1 & Terbaca \\
\hline & & 2 & Terbaca \\
\hline & & 3 & Terbaca \\
\hline \multirow{3}{*}{12} & \multirow{3}{*}{11} & 1 & Terbaca \\
\hline & & 2 & Terbaca \\
\hline & & 3 & Terbaca \\
\hline
\end{tabular}




\begin{tabular}{cccc}
\hline No. & Jarak $(\mathrm{cm})$ & Sampel Barcode & Keterangan \\
\hline \multirow{2}{*}{13} & \multirow{2}{*}{12} & 1 & Terbaca \\
& & 2 & Terbaca \\
& & 3 & Terbaca \\
14 & 13 & 1 & Terbaca \\
& & 2 & Tidak Terbaca \\
& & 3 & Terbaca \\
15 & 14 & 1 & Terbaca \\
& & 2 & Tidak Terbaca \\
& & 3 & Tidak Terbaca \\
16 & 15 & 1 & Tidak Terbaca \\
& & 2 & Tidak Terbaca \\
& & 3 & Tidak Terbaca \\
\hline
\end{tabular}

Berdasarkan hasil pada Tabel 3 tentang pengujian jarak pembacaan label barcode didapat beberapa kesimpulan. Kesimpulan diantaranya adalah dilihat dari tingkat keberhasilan label terbaca dan tidak terbaca, jarak minimal alat dapat membaca label barcode yaitu $1 \mathrm{~cm}$. Selanjutnya jarak maksimal alat dapat membaca label barcode adalah pada jarak $14 \mathrm{~cm}$. Jarak pembacaan label barcode dipengaruhi oleh kemampuan salah satu komponen dari sistem yaitu barcode scanner.

\subsection{Sudut Pembacaan Label Barcode dengan Scanner}

Pengujian pada sub ini menguji kemampuan alat dalam membaca label barcode dengan sudut pembacaan yang bervariasi. Digunakan 3 buah sampel label barcode barang dalam pengujian kali ini. Pengujian dilakukan dengan pembacaan label dari sudut yang terkecil sampai sudut yang terbesar yang mungkin diterapkan. Penambahan sudut dilakukan sebesar $10^{\circ}$ sampai sudut maksimal muka label terbaca, Tabel 4 menampilkan hasil pengujian yang dilakukan.

Tabel 4. Sudut Pembacaan Label Barcode dengan Scanner

\begin{tabular}{|c|c|c|c|}
\hline No. & $\begin{array}{c}\text { Sudut } \\
\left(\text { derajat } /{ }^{\circ}\right)\end{array}$ & $\begin{array}{c}\text { Sampel } \\
\text { Barcode }\end{array}$ & Keterangan \\
\hline \multirow{4}{*}{1} & & 1 & Tidak Terbaca \\
\hline & 0 & 2 & Tidak Terbaca \\
\hline & & 3 & Tidak Terbaca \\
\hline & & 1 & Tidak Terbaca \\
\hline \multirow[t]{3}{*}{2} & 10 & 2 & Tidak Terbaca \\
\hline & & 3 & Tidak Terbaca \\
\hline & & 1 & Terbaca \\
\hline \multirow[t]{3}{*}{3} & 20 & 2 & Terbaca \\
\hline & & 3 & Terbaca \\
\hline & & 1 & Terbaca \\
\hline \multirow[t]{3}{*}{4} & 30 & 2 & Terbaca \\
\hline & & 3 & Terbaca \\
\hline & & 1 & Terbaca \\
\hline \multirow[t]{3}{*}{5} & 40 & 2 & Terbaca \\
\hline & & 3 & Terbaca \\
\hline & & 1 & Terbaca \\
\hline \multirow[t]{3}{*}{6} & 50 & 2 & Terbaca \\
\hline & & 3 & Terbaca \\
\hline & & 1 & Terbaca \\
\hline \multirow[t]{2}{*}{7} & 60 & 2 & Terbaca \\
\hline & & 3 & Terbaca \\
\hline
\end{tabular}

Tabel 4. Sudut Pembacaan Label Barcode dengan Scanner (Lanjutan)

\begin{tabular}{cccc}
\hline No. & $\begin{array}{c}\text { Sudut } \\
\left(\text { derajat } /{ }^{\circ}\right)\end{array}$ & $\begin{array}{c}\text { Sampel } \\
\text { Barcode }\end{array}$ & Keterangan \\
\hline \multirow{2}{*}{8} & \multirow{2}{*}{70} & 1 & Terbaca \\
& & 2 & Terbaca \\
& & 3 & Terbaca \\
9 & \multirow{2}{*}{80} & 1 & Terbaca \\
& & 2 & Terbaca \\
& & 3 & Terbaca \\
10 & \multirow{2}{*}{90} & 1 & Terbaca \\
& & 2 & Terbaca \\
& & 3 & Terbaca
\end{tabular}




\begin{tabular}{|c|c|c|c|}
\hline No. & $\begin{array}{c}\text { Sudut } \\
\left(\text { derajat } /{ }^{\circ}\right)\end{array}$ & $\begin{array}{c}\text { Sampel } \\
\text { Barcode }\end{array}$ & Keterangan \\
\hline \multirow{3}{*}{11} & \multirow{3}{*}{100} & 1 & Terbaca \\
\hline & & 2 & Terbaca \\
\hline & & 3 & Terbaca \\
\hline \multirow{3}{*}{12} & \multirow{3}{*}{110} & 1 & Terbaca \\
\hline & & 2 & Terbaca \\
\hline & & 3 & Terbaca \\
\hline \multirow{3}{*}{13} & \multirow{3}{*}{120} & 1 & Terbaca \\
\hline & & 2 & Terbaca \\
\hline & & 3 & Terbaca \\
\hline \multirow{3}{*}{14} & \multirow{3}{*}{130} & 1 & Terbaca \\
\hline & & 2 & Terbaca \\
\hline & & 3 & Terbaca \\
\hline \multirow{3}{*}{15} & \multirow{3}{*}{140} & 1 & Terbaca \\
\hline & & 2 & Terbaca \\
\hline & & 3 & Terbaca \\
\hline \multirow{3}{*}{16} & \multirow{3}{*}{150} & 1 & Terbaca \\
\hline & & 2 & Terbaca \\
\hline & & 3 & Terbaca \\
\hline \multirow{3}{*}{17} & \multirow{3}{*}{160} & 1 & Terbaca \\
\hline & & 2 & Terbaca \\
\hline & & 3 & Terbaca \\
\hline \multirow{3}{*}{18} & \multirow{3}{*}{170} & 1 & Tidak Terbaca \\
\hline & & 2 & Tidak Terbaca \\
\hline & & 3 & Tidak Terbaca \\
\hline \multirow{3}{*}{20} & \multirow{3}{*}{180} & 1 & Tidak Terbaca \\
\hline & & 2 & Tidak Terbaca \\
\hline & & 3 & Tidak Terbaca \\
\hline
\end{tabular}

Hasil yang ditunjukkan Tabel 4 mengenai pengujian sudut pembacaan label barcode didapat beberapa kesimpulan. Kesimpulan diantaranya adalah dilihat dari tingkat keberhasilan label terbaca dan tidak terbaca, sudut minimal alat dapat membaca label barcode yaitu 20 derajat. Selanjutnya sudut maksimal alat dapat membaca label barcode adalah pada sudut 160 derajat. Seperti dalam percobaan sub bab 3.4., performa pembacaan label barcode dipengaruhi oleh komponen barcode scanner. Kemampuan pembacaan label yaitu dari sudut 20 sampai 160 derajat antara label dengan barcode scanner.

\subsection{Lama Penyimpanan Data}

Salah satu variabel yang dapat dijadikan tolok ukur untuk menggambarkan bagaimana keandalan dari suatu sistem adalah kecepatan. Dalam pembangunan sistem informasi bebasis web ini salah satu bagian yang memiliki unsur kecepatan dalam kerjanya adalah waktu lama penyimpanan data kedalam basis data.

Pengujian dilakukan dengan cara yang sistematis, semua label barcode dimasukkan datanya ke dalam basis data. Proses scanning (input) data label barcode barang dilakukan secara berurutan dan terus - menerus. Dilakukan proses tersebut dengan tujuan menghindari jeda yang terlalu lama antara peng-input-an barang yang satu dengan yang selanjutnya, sehingga didapatkan data waktu barcode tersimpan dengan faktor manusia yang dapat diabaikan, dan didapatkan waktu penyimpanan data yang hanya merujuk pada lama sistem dapat menyimpan data barcode yang baru. Tabel 5 merupakan hasil pengujian lamanya penyimpanan data.

Tabel 5. Lama Penyimpanan Data

\begin{tabular}{ccccc}
\hline No. & Nama & Kode & Waktu & Selisih Waktu Antar Data \\
\hline 1 & Barang A & 1 & 2019-05-03 21:19:37 & 5 detik \\
2 & Barang B & 2 & 2019-05-03 21:19:42 & 5 detik \\
3 & Barang C & 3 & 2019-05-03 21:19:47 & 5 detik \\
4 & Barang D & 4 & 2019-05-03 21:19:52 & 5 detik \\
5 & Barang E & 5 & 2019-05-03 21:19:57 & 5 detik \\
6 & Barang F & 6 & $2019-05-0321: 20: 02$ & 5 detik \\
7 & Barang G & 7 & $2019-05-0321: 20: 08$ & 5 detik \\
8 & Barang H & 8 & $2019-05-0321: 20: 13$ & 5 detik \\
9 & Barang I & 9 & $2019-05-03 ~ 21: 20: 18$ & 5 detik \\
10 & Barang J & 10 & $2019-05-0321: 20: 23$ & 5 detik \\
\hline
\end{tabular}

Sistem Informasi Pengiriman Barang di Gudang Distribusi dengan Sistem Barcode Berbasis Web (Dony Samara) 
Berdasarkan hasil pada Tabel 5. tentang lama penyimpanan data, didapat nilai waktu yang bervariasi. Dengan metode pengambilan data yang telah dikemukakan sebelumnya. Didapat jeda waktu yang berbeda beda antara data yang masuk, untuk mengetahui rata - rata lama penyimpanan data dilakukan pembahasan dalam perhitungan berikut ini:

$$
\begin{aligned}
& \text { Waktu rata - rata }(\bar{X})=\frac{\text { Jumlah waktu }}{\text { banyak nilai }} \\
& \qquad \begin{aligned}
\bar{X} & =\frac{5+5+5+5+5+6+5+5+5}{9}=\frac{46}{9} \\
\bar{X} & =5,1 \text { detik }
\end{aligned}
\end{aligned}
$$

Hasil perhitungan menunjukkan rata - rata jeda waktu masuk antara data 1 dengan yang lainnya adalah 5,1 detik. Kemampuan sistem menyimpan data yaitu rata - rata 5,1 detik dipengaruhi oleh kemampuan hardware dan software dalam mengolah data, dalam penelitian ini hal yang paling berpengaruh adalah kecepatan internet didalam sistem.

\section{KESIMPULAN}

Berdasar pada hasil penelitian dapat diambil beberapa kesimpulan, telah berhasil dibangun sistem informasi yang dapat memenuhi revolusi industri 4.0 yaitu sistem informasi pengiriman barang di gudang distribusi berbasis web. 5 jenis pengujian yang dilakukan mendapatkan hasil yang baik. 2 uji ketepatan berhasil dengan keseluruhan data tepat. 2 pengujian keandalan pembacaan barcode mendapatkan hasil sudut pembacaan minimal 20 derajat dan maksimal 160 derajat, dan jarak minimal scan (pembacaan) sejauh $1 \mathrm{~cm}$ dengan jarak maksimal sejauh $14 \mathrm{~cm}$. Pengujian yang terakhir yaitu lamanya sistem menyimpan data baru, didapatkan hasil rata - rata 5,1 detik jeda waktu masuk antar data. Penelitian ini dapat dikembangkan lebih lanjut dengan meningkatkan keandalan sistem, yaitu tampilan serta keamanannya dan untuk aplikasi lain yang berhubungan dengan sistem informasi, barcode, dan IoT (Internet of Thing).

\section{UCAPAN TERIMA KASIH}

Ucapan terima kasih penulis haturkan kepada editor dan reviewer atas segala saran, masukan dan bantuannya dalam proses penerbitan jurnal ini. Ucapan terima kasih selanjutnya penulis haturkan kepada semua pihak yang tidak dapat penulis sebut satu-persatu, yang telah memberikan berbagai bentuk dukungan dalam pelaksanaan penelitian ini.

\section{REFERENSI}

[1] H. Prasetyo, and W. Sutopo, "Industri 4.0: Telaah Klasifikasi Aspek dan Arah Perkembangan Riset," J@ti Undip, vol. 13, no. 1, pp. 17-26, Mar. 2018.

[2] Satya, V. E., "Strategi Indonesia Menghadapi Industri 4.0," Info Singkat, vol. 10, no. 09/I/Puslit, Mei. 2018.

[3] Padmantyo, S. and Saputra, A., "Peranan Manajemen Rantai Pasokan Terhadap Kualitas Produk dan Efisiensi Distribusi," in Seminar Nasional dan The 4th Call for Syariah Paper (SANCALL), 2017.

[4] Indonesia. Kementrian Perdagangan. Kajian Pengembangan Jasa Pergudangan di Indonesia. Jakarta: Pusat Kebijakan Perdagangan Dalam Negeri, 2015.

[5] 'Ainun C.N., R. \& Bakhtiar, A., "Penyusunan Barcode dan Penentuan Reorder Point Material 07 pada Gudang Bahan Kimia Studi Kasus PT. Pupuk Sriwidjadja Palembang," Industrial Engineering Online Journal (IEOJ), pp. 1-7, 2015.

[6] Shofa, H.K.M., "Sistem Informasi Persediaan Barang Menggunakan Metode Economic Order Quality pada Goodrich Gallery Semarang". Jurnal Ilmiah Komputer Akutansi (KOMPAK), " vol. 10(1), pp. 1-13, 2017.

[7] Syahriani, Santoso, T., dan Rizki, A.P. "Penerapan Sistem Informasi Web Penjualan Furniture," in Simposium Nasional Ilmu Pengetahuan dan Teknologi (SIMNASIPTEK), 2016.

[8] Kadir, A., Arduino: Panduan Mempelajari Aneka Berbasis Mikrokontroler, Yogyakarta: Andi, 2015.

[9] Nugroho, A., Konsep Pengembangan Sistem Basis Data, Bandung: Informatika, 2004.

[10] Riyanto, Membuat Aplikasi Mini Market Integrasi Barcode Reader dengan PHP dan MySQL, Yogyakarta: Gava Media, 2014.

[11] Wahyono, Teguh, Membuat Sendiri Aplikasi dengan Memanfaatkan Barcode, Jakarta: Elex Media Komputindo, 2010.

[12] Syafii, M., Panduan Membuat Aplikasi Database Dengan PHP 5, MySQL, PostgreSQL, Oracle, Yogyakarta: Andi, 2005. 


\section{BIOGRAFI PENULIS}

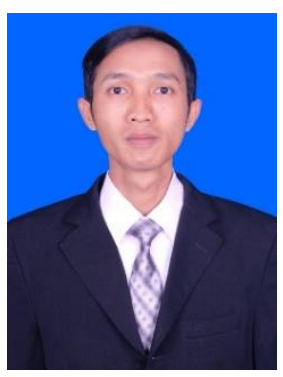

Dony Samara

Adalah mahasiswa yang telah menyelesaikan pendidikan S1 Teknik Elektro di Universitas Ahmad Dahlan Yogyakarta.

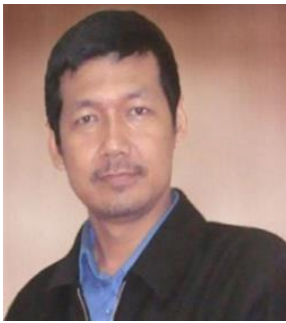

\section{Mushlihudin}

Menyelesaikan pendidikan S1 Teknik Elektro di Universitas Gajah Mada Yogyakarta dan S2

Teknik Elektro di Institut Teknologi Bandung. Bidang yang diminati beliau adalah Security, Web, \& Networking. Saat ini beliau menjabat sebagai staf pengajar Program Studi Tenik Informatika Universitas Ahmad Dahlan Yogyakarta. 